\title{
Partitioning of injuries caused by winter, fungal diseases and viral infections in cereals
}

\begin{abstract}
JARI PELTONEN
Peltonen, J. 1993. Partitioning of injuries caused by winter, fungal diseases and viral infections in cereals. Agric. Sci. Finl. 2: 353-356. Short communication. (Department of Plant Production, FIN-00014 University of Helsinki, Finland.)

The objective of this study was to clarify whether the critical levels of winter damage, viral infections and foliar diseases of cereals could be established by the Cate-Nelson procedure. This information would help the State Granary representatives and computer modelists, as well as farmers and consultants to understand the yearly variations in grain yields of cereals. Three winter rye, spring wheat and oat cultivars were used. The severity of leaf diseases and percentages of winter damage were observed visually. When winter damage exceeds $19 \%$, a yield reduction of $44 \%\left(1804 \mathrm{~kg} \mathrm{ha}^{-1}\right)$ in winter rye may be expected. The critical level of Septoria nodorum infection in spring wheat was $37 \%$. Above this critical level a yield reduction of $33 \%\left(1393 \mathrm{~kg} \mathrm{ha}^{-1}\right)$ was estimated. In oat canopy an area of $\geq 38 \%$ infected by barley yellow dwarf virus (BYDV) decreased the grain yield significantly by $30 \%\left(1718 \mathrm{~kg} \mathrm{ha}^{-1}\right)$.
\end{abstract}

Key words: winter rye, spring wheat, oats, winter damage, foliar diseases

\section{Introduction}

At the State Granary, decisions regarding import/export ratios of cereals are made retrospectively. In the absence of timely and exact yield data the decisions are inaccurate. The observations on the cereal crop are made by the Finnish Natioal Board of Agriculture, which has 300 - 400 representatives in different parts of the country. Yield estimates are based on visual observation. The results obtained by this method have shown that estimations may be inaccurate due to the paucity of observations. In addition, if growing conditions are abnormal (e.g. due to foliar diseases), the State Granary representatives may be unwilling to make extreme prognoses.

Recently TEITTINEN et al. (1993) developed a simple dynamic model based on daily climatolo- gical data, enabling prediction of crop growth, change in crop yield and grain quality. However, foliar diseases like Erysiphe graminis f. sp. tritici had a deleterious effect on grain yield of spring wheat and the prognoses on yield with the dynamic model failed (TEITTINEN et al. 1993). Therefore, it is preferable to determine the critical levels of winter damage, viral infections and fungal diseases of cereals. This information would help the State Granary representatives to estimate the final yield losses caused by the above mentioned stress factors, or to improve the prognostic value of the dynamic model developed by TEITTINEN et al. (1993).

\section{Material and methods}

The field trials were conducted in 1982-1988 at the Anttila Plant Breeding Farm (Hankkijan kasvinja- 


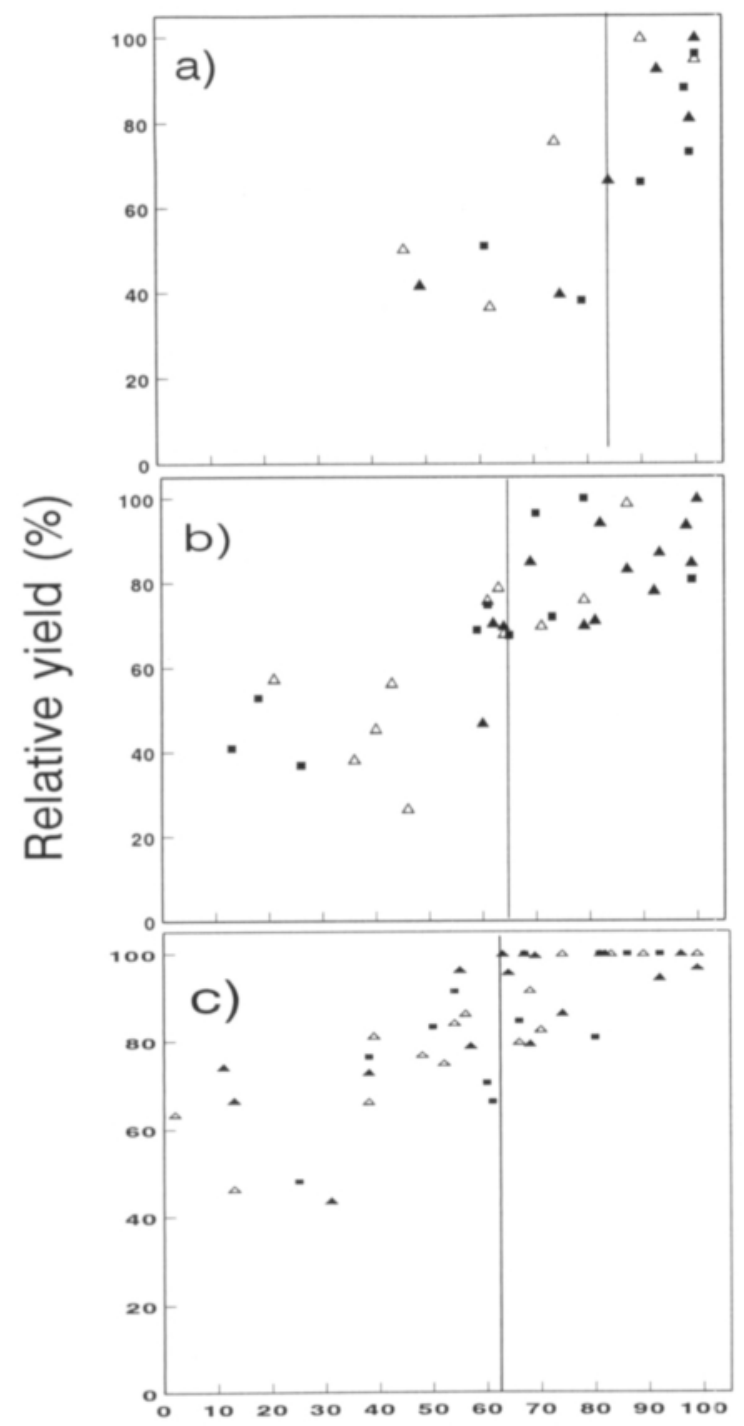

\section{Undamaged crop (\%)}

Fig. 1. Relative yields of three (a) winter rye cultivars as related to winter damage, (b) spring wheat cultivars as related to Septoria nodorum infection rate, and (c) oat cultivars as related to the barley yellow dwarf virus (BYDV) infection at the Anttila Plant Breeding Farm, 1982-1988. Cultivars: $=$ Hja Jussi winter rye, Ruso spring wheat, Caesar oats; $\boldsymbol{\Delta}=$ Sampo winter rye, Kadett spring wheat, Puhti oats; $\Delta=$ Voima winter rye, Ulla spring wheat, and Veli oats.

lostuslaitos 1982-1988). Winter rye cultivars $\mathrm{Hja}$ Jussi, Sampo and Voima, spring wheat cultivars Ulla, Ruso and Kadett, and oat cultivars Puhti, Veli
Table 1. Cate-Nelson equations describing grain yield $(\mathrm{Y})$ in relation to (1) overwintering in winter rye, (2) infected plant canopy of Septoria nodorum in spring wheat, and (3) disease development caused by barley yellow dwarf virus (BYDV) in oats.

Equation $\quad \mathrm{R}^{2}$
(1) $\mathrm{Y}=2294+1804 \cdot \mathrm{x}$ where $x=0$ if $\leq 81$ and 1 if $\geq 81(\%) \quad 0.68^{* * *}$
(2) $\mathrm{Y}=2791+1393 \cdot \mathrm{x}$ where $x=0$ if $\leq 63$ and 1 if $\geq 63(\%) \quad 0.48^{* * *}$
(3) $\mathrm{Y}=3948+1718 \cdot \mathrm{x}$ where $x=0$ if $\leq 62$ and 1 if $\geq 62(\%) \quad 0.51^{* * *}$

*** Significant at 0.001 probability level.

and Caesar (naked Cv.) were used. The fertilization levels used were those commonly applied in cereal cultivation in southern Finland. The percentage area of winter injury per plot in rye, and canopy infected by Septoria nodorum Berk. in spring wheat, and by barley yellow dwarf virus (BYDV) in oats were observed visually according to REKUNEN (1990). The critical levels of different stress factors were established using the Cate-Nelson analysis (CATE and NELSON 1971, NELSON and ANDERSEN 1977), a procedure widely used by soil scientists in evaluation of soil fertility and nutrient requirements of crops. Grain yield of a cultivar was expressed as a yield percentage $\left(\mathrm{Y}_{\mathrm{i}} / \mathrm{Y}_{\max } \times 100\right)$ where $\mathrm{Y}_{\mathrm{i}}$ stands for actual grain yields of a cultivar obtained in 1982-88 and $\mathrm{Y}_{\max }$ is the highest grain yield of a cultivar obtained in 1982-1988. The graphical Cate-Nelson method (NELSON and ANDERSEN 1977) was used (Fig. 1).

\section{The critical levels reducing the grain yields of cereals}

The critical level of winter damage for rye observed in the present study was $19 \%$ (Fig. 1a). When winter damage exceeds $19 \%$, a yield reduction of $1804 \mathrm{~kg} \mathrm{ha}^{-1}(44 \%)$ may be expected (equation 1, Table 1). The critical level of Septoria nodorum infection in spring wheat was $37 \%$ (Fig. 1b). According to the present results, yield losses caused by Septoria in an infected canopy of a cultivar ranking 
'low', as estimated by the Cate-Nelson procedure (equation 2, Table 1), average $2791 \mathrm{~kg} \mathrm{ha}^{-1}$ of grain yield as compared with an average yield of $4184 \mathrm{~kg}$ $\mathrm{ha}^{-1}$ for the 'optimum' class. In other words, above the critical infection rate $(\geq 37 \%)$ a yield reduction of $33 \%\left(1393 \mathrm{~kg} \mathrm{ha}^{-1}\right)$ can be expected. This result is an agreement with the earlier results of KARJALAINEN (1985) who reported decreases of kernel weight of $10-35 \%$ due to leaf and glume blotch (Septoria nodorum Berk.). Inversely, if the Septoria level in the canopy is $<37 \%$, no significant yield reduction will occur. Regarding BYDV in the canopy of oats, an area of $\geq 38 \%$ infected by BYDV decreased the grain yield significantly by $1718 \mathrm{~kg} \mathrm{ha}^{-1}$ (Fig. 1c, Table 1). This corresponds to a yield reduction of about $30 \%$. Similarly, a severe out-break of BYDV has been observed by KURPPA (1989) and PELTONEN-SAINIO and KARJALAINEN (1990) to cause $30-50 \%$ yield losses.

In conclusion, the Cate-Nelson model may provide useful information of yearly variations in grain yields of cereals to the State Granary representatives and computer modelists, as well as to farmers and consultants. However, this study was based on data collected by the Anttila Plant Breeding Farm. The data consisted of visual estimation of leaf diseases and winter damage only. Therefore, more detailed experiments are needed in future to determine the variation in critical levels in different locations and in different growth stages of cereals.

\section{References}

Cate, R.B. \& Nelson, J.A. 1971. A simple statistical procedure for partitioning soil test correlation data into two classes. Soil Sci. Am. Proc. 35: 658-660.

Hankkijan kasvinjalostuslaitos 1982-1988. Koetuloksia 1982-1988. Trial results. The Hankkija Plant Breeding Institute. Finland.

KarJalainen, R. 1985. Host-pathogen intecaction between spring wheat and Septoria nodorum with reference to resistance breeding. J. Agric. Sci. Finl. 57: 1-66.

KurPPA, S. 1989. Damage and control of Rhopalosiphum padi in Finland during the outbreak of 1988. Ann. Agric. Fenn. 28: 349-370.

Nelson, L.A. \& ANDERSEN, R.L. 1977. Partitioning of soil test crop response probability. In: Peck, T.R. et al. (eds.). Soil testing: Correlation and interpreting the analytical results. ASA Spec. Publ. 29. ASA, Madison. WI. p. 19-38.

Peltonen-Sainio, P. \& Karjalainen, R. 1990. Yield reduc- tion of oat cultivars in relation to disease development caused by barley yellow dwarf virus. J. Agric. Sci. Finl. 62: 265-273.

REKUNEN, M. 1990. ATK-koodit ja kenttähavaintojen suoritusohjeet. Hankkijan kasvinjalostuslaitos. Anttilan koetila. Hyrylä. 17 p.

Temtinen, M., Karvonen, T. \& Peltonen, J. 1993. A dynamic model for water and nitrogen limited growth in spring wheat to predict yield and quality. J. Agron. \& Crop Sci. (In press).

Manuscript received February 1993

Jari Peltonen

Department of Plant Production

Box 27, Viikki

FIN-00014 University of Helsinki, Finland 


\title{
SELOSTUS
}

\section{Eräiden stressitekijöiden raja-arvoja viljojen sadonmuodostuksessa}

\author{
JARI PELTONEN \\ Helsingin yliopisto
}

Tutkimuksessa määritettiin rukiin talvituhojen, kevätvehnän härmäsaastunnan ja kauran BYDV:n (ohran kääpiökasvuviruksen) rajaarvoja sadonmuodostuksen kannalta. Talvituhot rajoittivat rukiin sadonmuodostusta voimakkaasti, mikäli kylvetystä pinta-alasta oli tuhoutunut yli $19 \%$. Jos Septoriasaastunta oli voimakkaampi kuin $37 \%$, heikensi infektio satotasoa selvästi. BYDV:n aiheuttama satotappio oli merkittävä mikäli enemmän kuin $38 \%$ lehdistöstä oli saastunut. Kyseisten sadonmuodostusta rajoittavien stressien aiheuttama sadon menetys oli mallin mukaan rukiilla keskimäärin $44 \%$ (1804 kg/ha), kevätvehnällä $33 \%$ (1393 $\mathrm{kg} / \mathrm{ha}$ ) ja kauralla $30 \%$ (1718 kg/ha). Tutkimuksessa on pohdittu stressiraja-arvojen merkitystä arvioitaessa viljojen vuosittaisia satovaihteluita. 